\title{
The Evaluation of Use the Mobile Phone Learning English in Taiwan
}

\author{
Yi-Sheng Yu, Yu-Ying Lin, Yao-Lin Huang, and Wen-Hsu Hsieh
}

\begin{abstract}
This paper presents that how the students use their mobile phones to improve the way of learning English. A depth interview with the chief executive officer of LiveABC Interactive Corporation that has successfully developed interactive multimedia tools to learn English since 1997 and becomes one of the greatest English learning groups in Asia will also show us the benefits of using interactive multimedia platform in mobile phone to learn English in Taiwan.

A survey from the students will also prove that learning English use the mobile phone, not only the most convenient way but also the best way.
\end{abstract}

Index Terms -English learning, m-learning, mobile learning, i-phone.

\section{INTRODUCTION}

Language is the thing we used to communicate with other people. No matter what you want to do or what you want to said, you have to speak the language people can understand. And we all know that English has become the dominant international language. English is a means to communicate with foreigners, whether or not they are from English speaking countries. Its use is both increasing and vital for success in the fields of business, trade, diplomacy, science and education. So learning to communicate in English is an essential ability in today's global society. According to Johnson in World Englishes:

A great deal has been written about the spread of English [1], the new varieties of English in non-native speaking communities [2], [3], the teaching of English in an international context [4], [5], the role of English as an international medium of communication is necessary, that English is the language most widely accepted and used for this purpose, and that the intercomprehensibility of the different varieties of English used for international communication has to be ensured and maintained [6].

So, how to learn English and how to learn English more effectively especially using the interactive multimedia tools to learn English is very important.

In this digital days of time, Technology change everything, it also change various ways that people communicated. They communicate with short message; they communicate using

Manuscript received October 23, 2012; revised December 31, 2012.

Yi-Sheng Yu, Yao-Lin Huang, and Wen-Hsu Hsieh are with the Department of Computer and Communication Engineering, De Lin Institute of Technology, Taipei, Taiwan, R.O.C. (e-mail: tony@ dlit.edu.tw, yaolinhuang@gmail.com,win02@ dlit.edu.tw).

Yu-Ying Lin is with the Department of Business Administration, De Lin Institute of Technology, Taipei, Taiwan, R.O.C. (e-mail: roselin@ dlit.edu.tw). the Facebook, through computer, iPads, or cell phones. It also means that we can learn English via these mobile devices. With these devices, you can learn English while waiting lunch in the restaurant; learn English while waiting the bus or in the bus; learn English while in the Mall, you can even show the people what you want to say with mobile device while you are traveling to other country.

A lot of researches have been made about the use of mobile phones learning English language in different countries [7]-[11]. It also been reported that the ranking of Top Ten interesting ipod/iphone apps for English language learning [12]. With the emerging of mobile technologies, variety of features of current mobile applications could benefit the learners with enhanced learning environment while playing anywhere, anytime.

\section{METHOD AND RESUlts}

Lots of researches has been made and discussed about the using multimedia tools to learn English in recent years [13]-[15]. In Taiwan, the multimedia English learning platform developed by LiveABC Interactive Corporation which is most famous English learning groups in Taiwan is probably the best. A depth interview with the chief executive officer of LiveABC Interactive Corporation will show us the benefits of using interactive multimedia tools to learn English in all the four phases of language learning. (listening, speaking, reading and writing) The depth interview method refers to the quantitative research methods [16]-[17] has been widely used and discussed [19]-[22] will not be discussed here.

A survey by one hundred and forty undergraduate students at De Lin Institute of Technology who have completed a questionnaire in which, they made the comparison of the feeling to learn English with mobile phones and without them. And the weight on the questions will also show that the using mobile phones to learn English are the best way to learn English.

The benefits of using interactive multimedia tools to learn English will be presented separately in the four phases of language learning (listening, speaking, reading and writing) using the multimedia English learning platform in mobile phone developed by Live ABC Interactive Corporation.

\section{A. Listening Comprehension}

The platform offers the listening comprehension test that will make the learner "visualize" their listening comprehension memory. Learner can close the caption display function when they getting familiar with all the dialogue and also can use the slowly speak function to hear 
the dialogue more clearly as the Fig. 1 shows. These functions will improve your listening comprehension in a fast way.

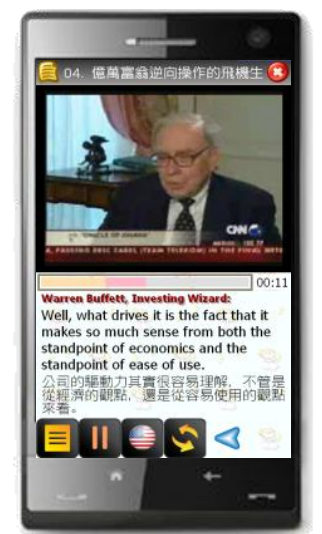

Fig. 1. "Visualize" their listening comprehension memory.

\section{B. Oral Proficiency}

The speech engine will check the pronunciation when you read the dialogue and the sensitivity of the engine can also be adjusted. That can enhance your oral proficiency. And the role play mode will let you practice the dialogue like real world situation.

\section{Reading}

Learner doesn't need to check the dictionary, all they have to do is to move the mouse to the unknown word and the engine will translate the word for you and give you some examples as Fig. 2 shows. And you can also put the new words in your personal memo list to review them in a fast way. And the translation function can make you more understand the meaning of the whole sentence. These functions will speed up your reading ability.

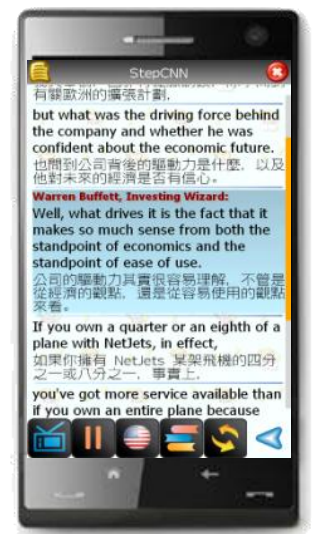

Fig. 2. No need to check the dictionary.

\section{Writing}

The dictation function will improve the learner's writing ability. The translation test function and the sentence reconstruction test function will also improve the learner's writing ability.

The results of the survey from one hundred and forty undergraduate students at De Lin Institute of Technology also agree with the results from what we have studied. Almost ninety-eight percent of the students have used multimedia platform to learn English. And eighty-six percent of the students have used the mobile phone Apps to learn English. Zero percent of the students prefer the traditional way to learn English. Thirteen percent of the students are not sure about the comparison. Eighty-five percent of the students enjoy that they can use mobile phone to learn English everywhere, anytime. Ninety percent of the students feel that it is very convenient for them to have mobile phone learning English while they travel to other country. The most important result is that seventy percent of the students willing to pay for the App if the translation is one hundred percent correct.

The results of the survey of what they think to learn English more effectively using mobile phone or the traditional method (teacher teaches in classroom) in the four phases of language learning (listening, speaking, reading and writing) are show as Table I:

TABLE I: THE PERCENTAGE OF WHAT STUDENTS THINK TO LEARN ENGLISH MORE EFFECTIVELY

\begin{tabular}{lclll}
\hline \hline & Mobile Phone & Not Sure & & Traditional \\
\hline Listening, & 84 & 15 & 1 & \\
Speaking & 81 & 16 & 3 & \\
Reading & 82 & 15 & 3 & \\
Writing & 74 & 22 & 4 & \\
Over all & 87 & 13 & 0 & \\
\hline \hline
\end{tabular}

The results show that learning English using the mobile phone is definitely more effectively than the traditional way not to mention conveniences. The same advantage goes with the terms from listening, speaking and reading but not that good at writing part.

Seventy-two percent of the students agree that using interactive multimedia tools to learn English can improve the ability in all the four phases of language learning. The same percent of the students will choose the interactive multimedia tools to learn English but the traditional way if they have the choice. And the main reason they don't choose the tools is they don't feel comfortable operating the interactive multimedia tools' platform.

\section{CONCLUSION}

Language is formed by habits through imitation, drill, repetition and reinforcement, the interactive multimedia tools which containing lots of films, pictures, and animations surly can engage students' interest and attention. It also definitely can motivate learners' willing to spend more time to learn English. A depth interview with the chief executive officer of Live ABC Interactive Corporation and the survey from one hundred and forty undergraduate students at De Lin Institute of Technology also proved that the using the mobile phone to learn English anywhere, anytime, not only can improve the ability in all the four phases of English learning with or without the teacher's company but also the best way to learn English more effectively.

\section{REFERENCES}

[1] J. A. Fishman, C. A. Ferguson, and Y. D. Gupta, Language problems of developing nations, New York: Wiley, 1968.

[2] Sociolinguistics: selected readings, edited by J. B. Pride and Janet Holmes, Harmondsworth, Penguin, 1972. 
[3] B. B. Kachru, The Other tongue : English across cultures, Urbana: University of Illinois Press, 1982

[4] M. Stevens and J. Mandel, Old English literature: twenty-two analytical essays, Lincoln: University of Nebraska Press, 1980.

[5] R. Quirk and H. G. Widdowson, "English in the world : teaching and learning the language and literatures," in Proc. International conference Progress in English Studies, London, September 1984, pp. $17-21$.

[6] R. Johnson, "International English: Towards an acceptable, teachable target variety," World Englishes, 1990, vol. 9, no. 3, pp. 301.

[7] A. Aamri and K. Suleiman, "The Use of Mobile Phones in Learning English Language by Sultan Qaboos University Students: Practices, Attitudes and challenges," Canadian Journal on Scientific \& Industrial Research, vol. 2, no. 3, March 2011.

[8] C.-M. Chen and S.-H. Hsu, "Personalized Intelligent Mobile Learning System for Supporting Effective English Learning," Educational Technology \& Society, vol. 11, no. 3, 2008, pp. 153-180.

[9] M. Tayebinik and M. Puteh, "Mobile Learning to Support Teaching English as a Second Language," Journal of Education and Practice, vol. 3, no. 7, 2012.

[10] Subrata Dey. (2009). English via Mobiles: Potential M-learners amongst Indian Students and Drivers. [Online]. Available: http://www.enablem.com/PDF/finalpaper2009india.pdf

[11] G. M. Chinnery, "Emerging Technologies Going to the Mall: Mobile Assisted Language Learning," Language Learning \& Technology, January, 2006, vol. 10, no. 1, pp. 9-16.

[12] G. Stanley. (2010). Top Ten interesting ipod/iphone apps for English $\begin{array}{llll}\text { language learning. } & \text { Anline]. }\end{array}$ http://www.digitalplay.info/blog/2010/05/01/top-ten-interesting-ipodi phone-apps-for-english-language-learning/

[13] C. Chapelle, Computer applications in second language acquisition: Foundations for teaching, testing, and research, Cambridge: Cambridge University Press. 2001.

[14] D. M. Chun and J. L. Plass, "Effects of multimedia annotations on vocabulary acquisition," Modern Language Journal, 1996, vol. 80, no. 2, pp. 183-212.

[15] D. M. Chun and J. L. Plass, "Research on text comprehension in multimedia environments," Language Learning \& Technology, 1997, vol. 1, no. 1, pp. 60-81.

[16] J. Butler, L. Rice, and A. Wagstaff, Quantitative Naturalistic Research, 1963, Englewood Cliffs, NJ., Prentice-Hall.

[17] A. Parkhe, “'Messy' research methodological prepositions, and theory development in international joint ventures," Academy of Management Review, vol. 18, no. 2, 1993, pp. 487-494.

[18] K. M. Eisenhardt, "Building theories from case study research," Academy of Management Review, vol. 14, no. 4, 1989, pp. 532-550.

[19] K. M. Eisenhardt, "Better stories and better constructs: the case for rigor and comparative logic," Academy of Management Review, vol. 16, no. 3, 1991, pp. 620-627.

[20] C. Perry and L. Coote, "Process of case study research methodology: toolfor management," in Proc. National Conference of the Australian-New Zealand Association of Management, Wellington, 1994, pp. 1-22.

[21] R. K. Yin, "Applications of Case Study Research," Applied Social Research Methods Series, 1993, vol. 5, Newbury Park, CA., Sage Publications.

[22] R. K. Yin, "Case Study Research-Design and Methods," Applied Social Research Methods Series, 1994, vol. 5, Newbury Park, CA., Sage Publications.

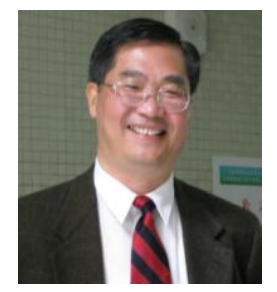

Yi-Sheng Yu was born on January 9th. 1964, in Taipei, Taiwan R.O.C.. He received the Ph.D. degree in Electrical Engineering from the University of Texas at Dallas U.S.A. in September 1994. From August 1986 to July 1988, he worked for his military service as a petty officer for Radar repair. From November 1988 to May 1989, he worked for the ACTEL Company as an Engineer From September 1989 to 1994 September, he persuaded his $\mathrm{Ph}$. D. degree and at the same time, he also being a teaching assistant of the Electrical Engineering Department for five years. From November 1994 to July 1995, he worked for the Chi-Yeh cell phone company as an Engineer. He was an associate professor of the Department of Electrical Engineering, De Lin Institute of Technology from August 1995 to
July 2001. Then he worked for the LiveABC Interactive Corporation as a Special Assistant of the C.E.O. from July 2000 to July 2001. From August 2001 to July 2002, he was the director of the computer center of the De Lin Institute of Technology. He was the chairman of the Electrical Engineering Department of De Lin Institute of Technology from August 2002 to July 2005. He was the chairman of the Computer and Communication Engineering Department of De Lin Institute of Technology from February 2006 to July 2009. From August 2009 to September 2010, he was the vice executive of Teaching Excellence Center of De Lin Institute of Technology. He was the Dean of the Duel Track Vocational Education Center of De Lin Institute of Technology from September 2010 to August 2011. His research interests include Multimedia Education, the application of grey system and optical communication.

Professor Yu is currently the Secretary-General of the De Lin Institute of Technology New Taipei City, Taiwan, R.O.C.

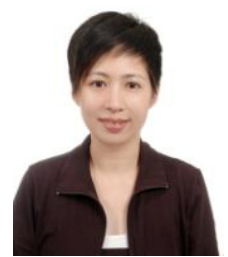

Yu-Ying Lin was born on January 29, 1971, in Taipei, Taiwan R.O.C.. She received the M.S. degree in Human Resource Development from Pittsburg State University U.S.A. in May 1996. From April 1997 to July 1997, she worked for Tait Marketing \& Distribution Co., Ltd. as a training assistant in Human Resource department. From August 1997 to 2012, she was the lecturer of the Department of Administration; De Lin Institute of Technology. Her research interests include Multimedia Education, Employee Recruiting Optimization.

Ms. Lin is currently the lecturer of the Department of Administration; De Lin Institute of Technology. New Taipei City, Taiwan, R.O.C..

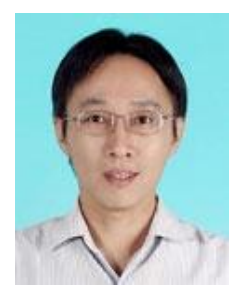

Yao-Lin Huang was born on March 9th, 1961, in Taoyuan, Taiwan, R.O.C.. He received the M.S. degree in Computer Science from the University of Missouri-Columbia, Columbia, MO in 1992, and the $\mathrm{Ph} . \mathrm{D}$. degree in Computer Science and Information Engineering from the National Taiwan University of Science and Technology, Taipei, Taiwan, R.O.C. in 2012. From November 1988 to August 1990, he worked for the Institute for Information Industry as a Software Engineer. From January 1993 to December 1993, he worked for the Southern Information Systems Inc. as a Research Engineer. He was the lecturer of General Education Center from January 1994 to July 2009, and Computer and Communication Engineering Department from August 2009 to October 2012 at De Lin Institute of Technology. His main research interests include Computational Intelligence, Time Series Forecasting, Image Processing, Parallel Computing, and Multimedia Education.

Dr. Huang is currently an Associate Professor with the Department of Computer and Communication Engineering, De Lin Institute of Technology, New Taipei City, Taiwan, R.O.C.

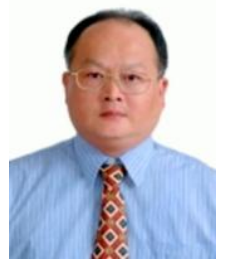

Wen-Hsu Hsieh was born on February 9, 1963, in Taipei, Taiwan R.O.C.. He received the master degree in Computer Science from the University of Oklahoma City, U.S.A. in May 1994. From October 1984 to July 1986, he worked for his military service as a marine's corps petty officer for mobile communication. From August 1986 to May 1990, he worked in the computer center of University of Aletheia as an Engineer. From May 1990 to 1994 May, he persuaded his bachelor and master degree at Oklahoma City University, U.S.A. He was an instructor of the Department of Computer Center, De Lin Institute of Technology from August 1994 to July 1997. From August 1997 to July 2007, he was the instructor of the General Education Center and also as a team leader of the Sector of The Academic section of the De Lin Institute of Technology. He was the instructor of the Computer and Communication Engineering Department and also as a Registration Team Leader of De Lin Institute of Technology from August 2008 until now. His research interests include Multimedia Education, the application of cloud computing and mobile communication

Currently, Professor Hsieh also is the PhD student of the Department of Electrical Engineering, National Taiwan University of Science and Technology, Taipei, Taiwan, R.O.C. 